\title{
Molecular Identification of Endophytic Fungi from Local Rice and Growth Test on Several Types of Culture Media
}

\section{Syamsia', Abubakar Idhan ${ }^{1}$, Amanda Patapparai ${ }^{1}$, Noerfitryani Noerfitryani², Rahmi Rahmi $^{3}$, Iradhatullah Rahim ${ }^{*}$}

1 Department of Agrotechnology, Universitas Muhammadiyah Makassar, Indonesia

2 Department of Agribusiness, Universitas Muhammadiyah Makassar, Indonesia

${ }^{3}$ Department of Aquaculture, Universitas Muhammadiyah Makassar, Indonesia

${ }^{4}$ Department of Agrotechnology, Universitas Muhammadiyah Pare-Pare, Indonesia

*Corresponding author's e-mail: iradhat76@gmail.com

How to Cite: Syamsia., Idhan, A., Patapparai, A., Noerfitryani., Rahmi., and Rahim, I. (2019). Molecular Identification of Endophytic Fungi from Local Rice and Growth Test on Several Types of Culture Media. Int. J. Agr. Syst. 7(2): 89-99

\begin{abstract}
Local rice is rice that has been cultivated for generations by the community and commonly cultivated without using chemical inputs. Endophytic fungi are fungi that live in the plant tissue and does not cause disease symptoms in the host plants. This study aimed to molecular identifying isolates of MDTA and MDTB endophytic fungi which have been isolated from the local Pulu Mandoti rice plant tissue and growth test on the four types of culture media those were synthetic PDA, natural PDA, MPA, and MEA. The fungi DNA isolation using DNesay Kit. DNA sequencing analysis using the mega BLAST program showed that the MDTB fungus has similarities to Podoscypha bolleana strain 32034 no accession JQ675334 and Podoscypha bolleana strain 32032 no accession JQ675332, whereas the MDTA fungus has similarities to Coprinopsis cinerea A2S3-5 isolate and Coprinopsis cinerea strain CNRMA / F 07-32. The best culture media and sporulation of endophytic fungi is MPA media. This research is the first study to molecular identifying with endophytic fungi from local rice and viability test on the four types of culture media. The results of this study contribute to the diversity of local rice endophytic fungi in Sulawesi.
\end{abstract}

Copyright (ㅇ) 2019 IJAS. All rights reserved.

\section{Keywords:}

Coprinopsis cinere; culture media; Podoscypha bolleana; Sporulation

\section{Introduction}

Endophytic fungi are microorganisms that live in plant tissues without causing symptoms of damage to plants (Hilarino et al., 2011; Afandhi et al., 2018). Endophytic fungi have been isolated from several types of plants such as: 1) Apple (Malus domestica) (Afandhi et al., 2018); 2) Orchid (Cymbidium aloifolim L) (Shubha \& Srinivas, 2017); 3) medicinal plant (Hedychium flavescens and Hedychium coronarium) (Uzma, Konappa, \& Chowdappa, 2016); 4) medicinal plant (Asclepias sinaica) (Fouda, Hassan, Eid, \& Ewais, 2015); 5) Medicinal Plant (Adhatoda vasica Nees, Coleus aromaticus Benth, 
Costus igneus N.E.Br and Lawsonia inermis Linn) (Amirita et al., 2012); 6) Wild rubber trees (Hevea brasiliensis) (Gazis \& Chaverri, 2010).

Endophytic fungi had an important role in agriculture such as stimulating or increasing plant growth, increasing plant resistance to pests, diseases, and nematodes, increasing plant resistance to drought stress. Some research results on the important role of endophytic fungi in agriculture are: 1) biocontrol agents for blast disease (Sucipto, Munif, Suryadi, \& Tondok, 2015); 2) spur plant growth (Saylendra \& Firnia, 2013) ; 3) biocontrol agent (Suciatmih, Yuliar, \& Supriyati, 2011); 4) increase resistance to pathogenic pests (G, A, \& Kannan, 2015); 5) increasing plant resistance to drought stress(Shukla, Awasthi, Rawat, \& Kumar, 2012); 6) protect host plants from pest attacks (Faeth, 2002).

Exploration of endophytic fungi has been carried out on several types of plants to obtain a collection of endophytic fungi that can be utilized in agricultural fields. Local rice plants are one of the plants that had the potential of endophytic fungi that need to be explored in depth because they have some potential. According to Sitaresmi, Wening, Rakhmi, Yunani, \& Susanto (2013), local rice naturally has resistance to pests and diseases, abiotic stress tolerant and has good rice quality and flavor favored by consumers in every location where the rice plant was cultivated.

Regional development centers of local rice in South Sulawesi are generally located in the mountainous area with an altitude $1000 \mathrm{~m}$ above sea level such us Tanah Toraja, Enrekang, and Luwu. Local rice varieties developed in Toraja are Pare Lalodo; Rogon; Pare Lea; Pare Kobo; Pare Ra'rari, Pare Ambo, Pare Tallang, Pare Bau; Pare Birrang and Pare Bumbungan (Juhriah, A.Masniawati, Tabaru, \& Astuti, 2013). While in Enrekang local rice was developed; Pare Salle; pare Pulu Lotong, pare Pinjan, pare Pulu Mandoti, pare Lambau, pare Pallan, Pare Solo, pare Mansur and pare Kamida (Maulana, Kuswinanti, Sennang, \& Syaiful, 2014). Luwu has 5 local rice varieties, namely: Tarone, Dambo, Kamba, Mandi, and Remaja.

Exploration and identification of endophytic fungi are very important because endophytic fungi have an important role in the ecosystem. Besides that, it can be used as information and as a basis for developing the potential of endophytic fungi. Some endophytic fungi have been isolated from rice plants and morphologically identified, namely: 1) Fusarium sp, Cladosporium sp, Phoma sp, Penicillium sp (Sucipto, Munif, \& Tondok, 2016); 2) Aspergillus sp1, Aspergillus sp2, Aspergillus candidus and Acremonium (Syamsia, 2016); 3) Nigrospora sp. 3, Penicillium, Trichoderma sp. 2, Nigrospora sp. 4, Verticillium, and brown sterile hyphae 2 (Asiah, Wiyono, \& Triwidodo, 2011).

Identification of fungi morphologically based on colonies and spores often less certainty of the identity of isolates. This is because the morphology endophytic fungi can be changed, other than that some endophytic fungus has very slow growth and frequent sporulation (Hyde dan Soytong 2008);(Legiastuti \& Aminingsih, 2012)). According to (Diaz, Hennell, \& Sucher, 2013), one solution to anticipate identification deficiencies morphologically is through molecular identification. 
Molecular identification of endophytic fungi using comparative analysis of ribosome DNA sequences, especially the Internal transcribed spacer (ITS) region using primary ITS2, ITS4 and ITS5 (Y.W. et al., 2009); primary ITS1 and ITS4 (Fernandes, Pereira, Silva, Bento, \& Queiroz, 2015) and primary ITS5 and ITS4 (Rakhmana, Rahayu, Ardhi, \& Wahyu, 2017); primary ITS1 and ITS2 (Alwakeel, 2013)

The types of culture media that can be used for fungi were Potato Dextrose Agar (PDA), Carrot Agar Potato (PCA), Sabouraud Dextrose Agar (SDA), Czapex Dox Agar (CDA), Corn Meal Agar (CMA), Nutrient Agar (NA), Malt Extract Agar (MEA) (Taurisia, Provorini, \& Nurantoro, 2000).

This study aimed to identify endophytic fungi isolates from Enrekang local rice plants and test the ability of fungi to grow on several types of media. The molecular identification of endophytic fungi from Enrekang local rice has never been done before, so this is the first study. In addition, growth test of local rice in several types of media. The results of this study will provide the benefits of the diversity of endophytic fungi from local rice and further research for the development of potential endophytic fungi as PGPF in increasing agricultural production.

\section{Materials and Method}

\subsection{Rejuvenation of Isolates and Endophytic Fungi DNA Extraction}

Two endophytic fungi isolate that were isolated from the roots and stems of Pulu Mandoti rice namely MDTB and MDTA were re-grown on PDA media. Mycelia of fungi isolates was harvested and extracted using DNesay DNA DNA kits from Qiagen. Miselia of fungi was taken and placed in mortal then crushed until smooth. Mycelia was inserted into the microtube that has been filled with $400 \mu 1$ buffer AP1, $40 \mu 1$ PVP $26 \%$ and $4 \mu \mathrm{l}$ RNase A stock $(100 \mathrm{mg} / \mathrm{ml})$ in the vortex then incubated in a water bath at $65^{\circ} \mathrm{C}$ for 30 minutes. The solution was then centrifuged.

\subsection{Fungi DNA amplification}

Endophytic fungi DNA amplification using primers ITS1 and ITS4. The amplification started with the manufacture of PCR mix consisting of hotstar mix PCR (Qiagen), Primer ITS 1 and ITS 4, DNA working and $\mathrm{DDh}_{2} \mathrm{O}$. The PCR mix solution was then inserted into the PCR machine for DNA amplification in vitro.

The PCR solution was inserted into the PCR machine and the amplification process started with an initial denaturation at $95^{\circ} \mathrm{C}$ for 5 minutes, denaturation at $94^{\circ} \mathrm{C}$ for 1 minute, annealing at $55.4^{\circ} \mathrm{C}$ for 1 minute and the final extension of $72^{\circ} \mathrm{C}$ for 10 minutes. The denaturation stage until the extension was repeated 35 times. The DNA amplification process lasts for \pm 2 hours 16 minutes.

\subsection{Separation Process of DNA Amplification Results}

DNA amplification product separation was carried out using a horizontal electrophoresis method. This method was used 2\% agarose and Tris Acetate EDTA (TAE) buffer $1 \mathrm{x}$. The results of separation then inserted in geldoc to see the results of 
separation used UV transuminator and documented. Separation DNA amplification product was repaired to determine whether the amplification process was successful or not and determine the size of the amplification product.

\subsection{DNA Sequencing Analysis}

PCR products that were successfully amplified from MDTB and MDTA endophytic fungi isolates were sent to Genetic science, Jakarta for sequencing. The sequencing results were then analyzed using the Basic Local Alignment Search Tool (BLAST)

\subsection{Growth Test on Four Types of Culture Media}

Growth test of both endophytic fungi isolates on four types of culture media was carried out by growing each isolate in synthetic Potato Dextrose Agar (PDA) media, natural PDA, Malt Extract Agar (MEA) and Malt Peptone Agar (MPA). Endophytic fungus mycelium of two isolates were grown on media, Synthetic PDA (synthetic PDA), natural PDA (made from potato extract), MEA (15 g malt extract, 16 g agar / L sterile water), MPA (15 g malt extract, 20 g glucose, 5 g peptone and 16 agar / L sterile water). The isolates were incubated at room temperature. The growth of two isolates was measured based on the colony diameter until the 7th day (Rahim et al. 2015)

\section{Results and Discussion}

\subsection{Molecular Identification}

The two of endophytic fungi isolates had different morphological characters, MDTB isolates were gray, the upper surface of the colony was compact and thick, the colony grows was very slow, small diameter $( \pm 1.25 \mathrm{~cm})$, the colony reverse was rather creamy. MDTB isolate was blackish white, smooth upper surface, the colony growth was very fast, large diameter $( \pm 8.89 \mathrm{~cm})$, colony reverse was white, the two isolates have concentric zones types.

Isolates DNA endophytic fungi were successfully amplified using primers pairs of ITS1 and ITS4 at an annealing temperature of $55.4^{\circ} \mathrm{C}$. The formation of DNA bands on an agarose gel after electrophoresis showed the PCR amplification process was successful. The success of PCR amplification was determined by the primer pairs and the corresponding annealing temperature in each fungus. This result was similar to the (Sibero et al., 2018), who succeeded in clarifying endophytic fungi R3 isolates isolated from coastal plants Hydnophytum formicarum from Sorong using primers pairs of ITS1 and ITS4. Likewise, the research of (Rahayu, Saryono, \& Nugroho, 2015), succeeded in amplifying the DNA PCR of endophytic fungi from LBKURCC69 isolates that had been isolated from dahlia bulbs in the area ITS-1 and ITS-2 rDNA and primer pairs of ITS4 and ITS5. Research (Alwakeel 2013) using primer pairs of ITS1 and ITS 2.

The results of electrophoresis analysis on the results of PCR produce a single band for each DNA amplification (Fig. 1). The size of the molecular weight of the two isolates was $700 \mathrm{bp}$. This result was different from the DNA band size of two endophytic fungi isolates isolated from dahlia plants, which were only 583 and 537 bp in size (Rakhmana 
et al., 2017), as well as the DNA size of endophytic fungi isolates from srikaya plants was 600 bp (Yunianto et al. 2012).

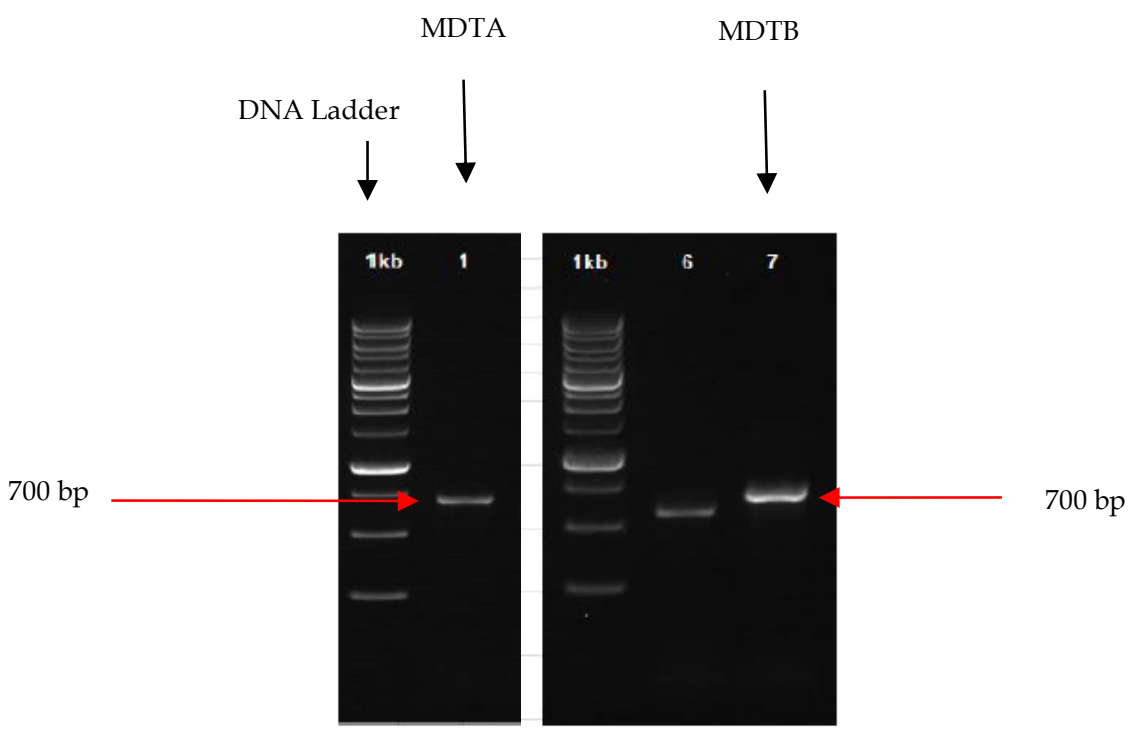

Fig. 1 The results of DNA amplification MDTB endophytic fungi isolates (1) and MDTA (7) using primers pairs of ITS1 and ITS4, DNA ladder $(1 \mathrm{~kb})$.

Determining the identity of fungi isolates conducted based on sequencing data of text files compared with the closest species sequence homologies in the sequence data in the database / NCBI GenBank (Hall, 2004; Nuryadi et al., 2016). The homology Blast results on DDBJ / NCBI conducted on 2 samples of endophytic fungi isolates were presented in Table 2 and Tabel 3

Table 2. The strains on NCBI GenBank Database having a close kinship to MDTB

\begin{tabular}{ccccccc}
\hline Species & \multirow{2}{*}{ Strain } & GenBank access code & Reference & Score & $\begin{array}{c}\text { Query } \\
\text { cover }\end{array}$ & $\begin{array}{c}\text { Max } \\
\text { identity }\end{array}$ \\
\hline Podoscypha bolleana & 32032 & JQ675332.1 & Langer, E (2012) & 1055 & $97 \%$ & $94,29 \%$ \\
Podoscypha bolleana & 32034 & JQ675334.1 & Langer, E (2012) & 1055 & $97 \%$ & $94,29 \%$ \\
\hline
\end{tabular}

Table 3. The strains on NCBI GenBank Database having a close kinship to MDTA

\begin{tabular}{ccccccc}
\hline Species & Strain & $\begin{array}{c}\text { GenBank acces } \\
\text { code }\end{array}$ & Reference & Score & $\begin{array}{c}\text { Query } \\
\text { cover }\end{array}$ & $\begin{array}{c}\text { Max } \\
\text { identity }\end{array}$ \\
\hline Coprinopsis cinerea & HN08 & JQ796875.1 & Zhang,Y. and Li, D. C (2012) & 1306 & $98 \%$ & $99,71 \%$ \\
Coprinopsis cinerea & A2S3-5 & KJ780765.1 & (Teh Li \& Latiffah, 2014) & 1317 & $98 \%$ & $99,71 \%$ \\
\hline
\end{tabular}

The results of identification using DNA barcoding proved that endophytic fungi from local Sulawesi Selatan rice with sample code 1 were homologs of Podoscypha bolleana strain 32034 no accession JQ675334 and Podoscypha bolleana strain 32032 no accession JQ675332 with 100\% similarity level and sample code 8 was a homolog of Coprinopsis cinerea isolate A2S3-5 with 99\% similarity level and Coprinopsis cinerea CNRMA / F 07-32 strain with 100\% similarity level. Research (Sibero et al., 2018) proved that RS3 fungus was a homolog of Annulohypoxylon stygium DR47 strain with 99\% similarity level, with accession number MG605083.1. Research 
by (Nuryadi et al., 2016), succeeded in identifying molecular fungi from dahlia tubers using ITS molecular markers, there were 4 isolates as Lasiodiplodia genus, 4 isolates as Didymellaceae family, 11 isolates were identified as Phomopsis genus, 5 isolates as Colletotrichum genus, 1 isolates as Nemania genus, and 1 isolate as Xylaria genus. Coprinopsis cinerea is a basidiomycete fungus that is used for many basic studies, including research into the fungus development stage. C. cinerea fungus was easy to maintain, has a short life cycle and can be induced to develop fruit bodies in the laboratory and only takes 2 weeks to produce a ripe fruit body.

The sequence results created in the FASTA format for phylogenetic tree construction using MEGA7. The tree was constructed using UPGMA models and Kimura-2Parameter genetic distances. In the process of making the tree, Podoscypha bolleana Strain 32032, P. bolleana Strain 32034 having a close kinship to MDTA (Table 2.) and Coprinopsis cinereaStrain HN08 and C. cinerea A2S3-5 having a close kinship to MDTB (Table 3.).

Dendogram based on the similarity value of the strain obtained from Gen-Bank. Each morphotype was grouped together and separated from each other. The phylogenetic tree produced (Fig 2). The tree showed that the position of the sample with its relative species. The position of MDTA with MDTB in the phylogenetic tree lies in one cluster so it showed that they were closely related. The genetic distances between MDTA and MDTB samples were calculated using the Kimura-2-Parameter method in MEGA7 according to (Kumar, Stecher, \& Tamura, 2016). The results showed that the genetic distances between MDTA and MDTB with the highest boostrap value at $93 \%$. These results indicate them likely that MDTA and MDTB endophytic fungi are closely related and even tend to be subspecies

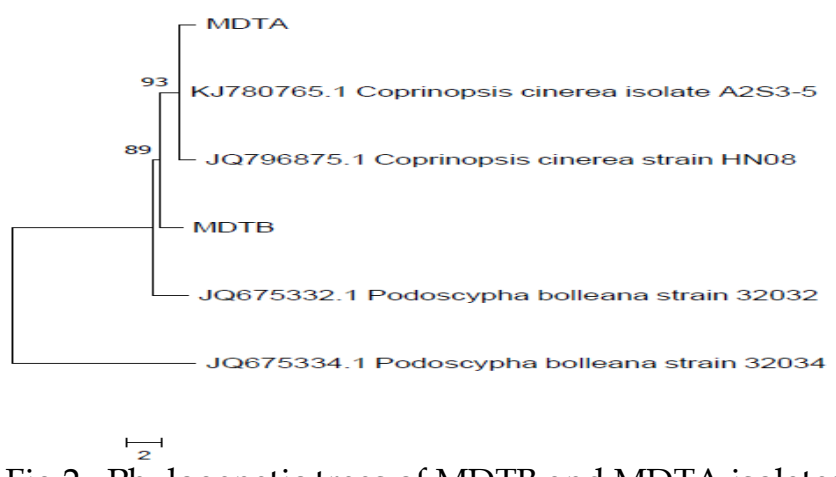

Fig 2. Phylogenetic trees of MDTB and MDTA isolates

3.2 The Growth of endophytic fungi in four type of media

The growth of the two endophytic fungi isolates in four types of media showed that the diameter of the colonies, the color of the upper surface, the upper surface and zoning were basically the same for all types of media, except for texture and sporulation there were differences in MEA media, the texture of the two isolates very 
thin in the MEA medium and sporulate sporulation was very poor (Table 5 and Table $6)$.

Table 5. Growth of MDTB isolates in four media

\begin{tabular}{|c|c|c|c|c|c|c|}
\hline \multirow[t]{2}{*}{ Media } & \multirow{2}{*}{$\begin{array}{l}\text { Colony } \\
\text { Diameter } \\
(\mathrm{cm})\end{array}$} & \multicolumn{2}{|c|}{ Colony character } & \multirow[b]{2}{*}{$\begin{array}{l}\text { Colony } \\
\text { Reverse }\end{array}$} & \multirow[b]{2}{*}{ Zonation } & \multirow[b]{2}{*}{ Sporulation } \\
\hline & & Texture & $\begin{array}{l}\text { Upper } \\
\text { Surface } \\
\text { Color }\end{array}$ & & & \\
\hline Synthetic PDA & 2.23 & $\begin{array}{c}\text { Thick } \\
\text { compact }\end{array}$ & Gray & Cream & $\begin{array}{l}\text { Concentric } \\
\text { zones }\end{array}$ & Average \\
\hline Natural PDA & 2.33 & $\begin{array}{l}\text { Thick } \\
\text { compact }\end{array}$ & Gray & Cream & $\begin{array}{l}\text { Concentric } \\
\text { zones }\end{array}$ & Average \\
\hline MPA & 2.30 & $\begin{array}{l}\text { Thick } \\
\text { compact }\end{array}$ & Gray & Cream & $\begin{array}{c}\text { Concentric } \\
\text { zones }\end{array}$ & Much \\
\hline MEA & 2.02 & Thin growth & Gray & Cream & $\begin{array}{c}\text { Concentric } \\
\text { zones }\end{array}$ & Little/ Less \\
\hline
\end{tabular}

Table 6. Growth of MDTA isolates on four media

\begin{tabular}{|c|c|c|c|c|c|c|}
\hline \multirow[t]{2}{*}{ Media } & \multirow{2}{*}{$\begin{array}{l}\text { Colony } \\
\text { Diameter } \\
\quad(\mathrm{cm})\end{array}$} & \multicolumn{2}{|c|}{ Colony character } & \multirow[b]{2}{*}{$\begin{array}{l}\text { Colony } \\
\text { Reverse }\end{array}$} & \multirow[b]{2}{*}{ Zonation } & \multirow[b]{2}{*}{ Sporulation } \\
\hline & & Texture & $\begin{array}{c}\text { Upper } \\
\text { Surface } \\
\text { Color }\end{array}$ & & & \\
\hline Synthetic PDA & 8.25 & Furry & $\begin{array}{c}\text { Blackish } \\
\text { white }\end{array}$ & White & $\begin{array}{c}\text { Concentric } \\
\text { zones }\end{array}$ & Average \\
\hline Natural PDA & 8.43 & Furry & $\begin{array}{c}\text { Blackish } \\
\text { white }\end{array}$ & White & $\begin{array}{c}\text { Concentric } \\
\text { zones }\end{array}$ & Average \\
\hline MPA & 8.89 & Furry & $\begin{array}{c}\text { Blackish } \\
\text { white }\end{array}$ & White & $\begin{array}{c}\text { Concentric } \\
\text { zones }\end{array}$ & Much \\
\hline MEA & 6.34 & Thin growth & $\begin{array}{c}\text { Blackish } \\
\text { white }\end{array}$ & White & $\begin{array}{c}\text { Concentric } \\
\text { zones }\end{array}$ & Little/ Less \\
\hline
\end{tabular}

The growth of MDTB endophytic fungi isolates in four types of media namely synthetic PDA, natural PDA, MPa and MEA (Fig. 3). Both endophytic fungi isolates have the ability to grow well in all three types of media, namely PDA Synthetic, natural PDA and MPA. The media suitable for sporulation was MPA media. The result of this study was similar to research (Rahim, Kuswinanti, Asrul, \& Rasyid, 2015) who was found MPA media as the best medium for foliage fungus growth. However, different research result (Devi, Misra, Saha, Devi, \& Sinha, 2018) was getting the best media for fungi sporulation were MEA and OMA. 


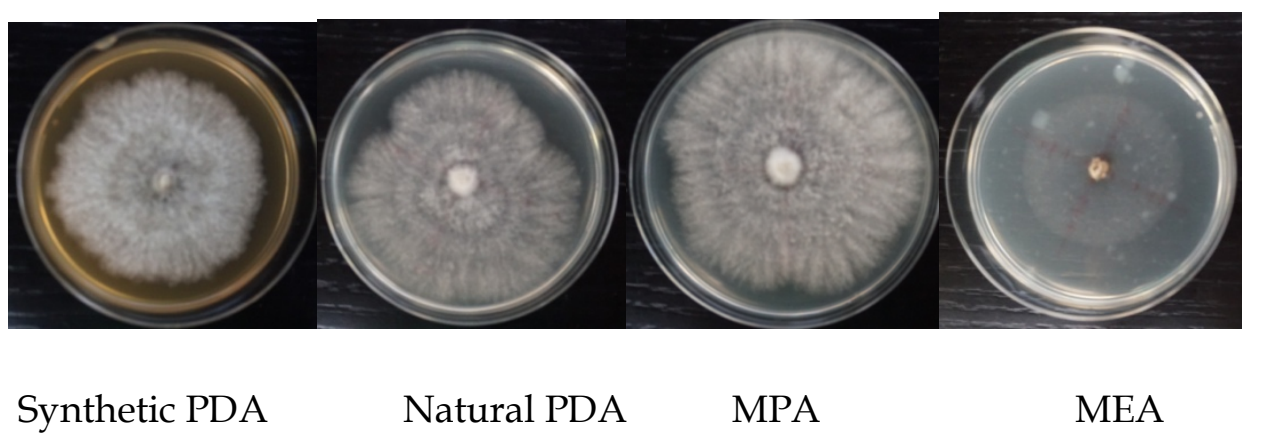

Fig. 3 The growth of MDTB endophytic fungi isolates in four types of media: Synthetic PDA (A), Natural PDA (B), MPA (C) and MEA (D)

In general, natural PDA media and synthetic PDA were still suitable for growth and sporulation of endophytic fungi. The result of the study (Noerfitryani \& Hamzah, 2017), who use PDA media for the growth of Fusarium, Aspergillus and Trichoderma fungi. According to (Devi et al., 2018) PDA media was a medium commonly used for fungus growth because the formulation was simple and has the ability to support the growth of mycelia in almost all types of fungi. Likewise, research (Aini \& Rahayu, 2015) showed that PDA media provide the best growth of fungi Candida albicans and Aspergillus niger than alternative media.

\section{Conclusion}

The MDTB fungus has similarities to Podoscypha bolleana strain 32034 no accession JQ675334 and Podoscypha bolleana strain 32032 no accession JQ675332, whereas the MDTA fungus has similarities to Coprinopsis cinerea A2S3-5 isolate and Coprinopsis cinerea strain CNRMA/F 07-32. The best culture media and sporulation of endophytic fungi is MPA media.

\section{Acknowledgements}

The author would like to thank Ristekdikti who has funded this research through Higher Education Basic Research Scheme based on the Decree of the Director General of Strengthening Research and Development of the Ministry of Research, Technology and Higher Education of the Republic Indonesia Number 3/E/KPT/2018 on Acceptance of Research Funding in Higher Education in 2018

\section{References}

Afandhi, A., Choliq, F. A., Havinda Anggrilika, W. S., \& Tarno, H. (2018). Distribution of the endophytic fungi in apple leaves. Agrivita $40: 91-100$

Aini, N., \& Rahayu, T. (2015). Alternatif Media for Fungal Growth Using a Different Source of Carbohidrats Nurul. In Seminar Nasional XII Pendidikan Biologi FKIO: 861-866 [Indonesian] 
Alwakeel, S. S. (2013). Molecular identification of isolated fungi from stored apples in Riyadh, Saudi Arabia. Saudi Journal of Biological Sciences 20 : 311-317.

Amirita, A., Sindhu, P., Swetha, J., Vasanthi, N. S., \& Kannan, K. P. (2012). Enumeration of endophytic fungi from medicinal plants and screening of extracellular enzymes. Word Journal of Science and Technolgy 2 : 13-1.

Asiah, N., Wiyono, S., \& Triwidodo, H. (2011). Keanekaragaman dan Kelimpahan Cendawan Endofit pada Batang Padi. [Skripsi]. Institut Pertanian Bogor [Indonesian]

Devi, K. S., Misra, D. K., Saha, J., Devi, P. S., \& Sinha, B. (2018). Screening of Suitable Culture Media for Growth, Cultural and Morphological Characters of Pycnidia Forming Fungi. International Journal of Current Microbiology and Applied Sciences 7: 4207-4214.

Diaz, P. L., Hennell, J. R., \& Sucher, N. J. (2013). Chapter 14 Genomic DNA Extraction and Barcoding of Endophytic Fungi. In Methods in Molecular Biology :171-179.

Faeth, S. H. (2002). Are endophytic fungi defensive plant mutualists? Oikos $9: 25-36$.

Fernandes, E. G., Pereira, O. L., Silva, C. C. da, Bento, C. B. P., \& Queiroz, M. V. de. (2015). Diversity of endophytic fungi in Glycine max. Microbiological Research $181: 84-92$.

Fouda, A. H., Hassan, S. E. D., Eid, A. M., \& Ewais, E. E. D. (2015). Biotechnological applications of fungal endophytes associated with medicinal plant Asclepias sinaica (Bioss.). Annals of Agricultural Sciences, 60 : 95-104.

G, A. K., A, R. A., \& Kannan, V. R. (2015). Exploration of endophytic microorganisms from selected medicinal plants and their control potential to multi drug resistant pathogens. Journal of Medicinal Plant Studies $3: 49-57$.

Gazis, R., \& Chaverri, P. (2010). Diversity of fungal endophytes in leaves and stems of wild rubber trees (Hevea brasiliensis) in Peru. Fungal Ecology $3: 240-254$.

Hilarino, M. P. A., Silveira, F. A. de O. e, Oki, Y., Rodrigues, L., Santos, J. C., Corrêa Junior, A., ... Rosa, C. A. (2011). Distribution of the endophytic fungi community in leaves of Bauhinia brevipes (Fabaceae). Acta Botanica Brasilica, 25(4), 815-821.

Hyde KD, Soytong K. 2008. The fungal endophyte dilemma. Fungal Divers. 33:163173.

Juhriah, A.Masniawati, Tabaru, E., \& Astuti, S. (2013). Morphological Characterization of Panicle Landrice's from North Tana Toraja South Sulawesi. Jurnal Sainsmat II : 22-23.[Indonesian]

Kumar, S., Stecher, G., \& Tamura, K. (2016). MEGA7: Molecular Evolutionary Genetics Analysis Version 7.0 for Bigger Datasets. Molecular Biology and Evolution 33 :1870-1874.

Langer,E, (2017). Molecular phylogeny of Podoscypha (Basidiomycota, Meruliaceae) with description of a new genus, Crinipileoscypha gen. nov., inferred from nuclear and mitochondrial rDNA sequences; Unpublished

Legiastuti, T. S., \& Aminingsih, T. (2012). Detection of Endophytic Fungi Using Polymerase Chain Reaction Technique. Fitopatologi Indonesia 8:31-36.

Maulana, Z., Kuswinanti, T., Sennang, N. R., \& Syaiful, S. A. (2014). Genetic Diversity Of Locally Rice Germplasm From Tana Toraja And Enrekang Based On RAPD ( 
Random Amplified Polymorphism DNA ) Markers. International Journal of Scientific \& Technology Research 3 : 198-202.

Noerfitryani, N., \& Hamzah, H. (2017). The Existence of Entomopatogenic Fungi on Rice Plants Rhizosphere. Internasional Journal of Bioscience and Biotechnology 5 :12-24.

Nuryadi, W., Rakhmawati, A., \& Prihatini, I. (2016). Isolation and Identification of Endophytic Fungi of Sengon Trees Provenance Solomon Islands Based On Morphological and Molecular (Analysis of rDNA ITS (Internal Transcribed Spacer). Jurnal Biologi $5: 15-27$.

Rahim, I., Kuswinanti, T., Asrul, L., \& Rasyid, B. (2015). Screening of Fungal Rot Isolates from Cocoa as Phosphate-Dissolving and their Growth Ability on Three Types of Media. Procedia Food Science 3 : 104-111.

Rakhmana, S., Rahayu, F., Ardhi, A., \& Wahyu, N. (2017). Molecular identification of endophytic fungi isolated from the tuber of Dahlia variabilis and exploration of their ability in producing $B$ - galactosidase. Biodiversitas $18: 145-152$.

Saylendra, A., \& Firnia, D. (2013). Potensi Cendawan Endofit Perakaran Jagung Sebagai Pemacu Pertumbuhan Tanaman. Jurnal Ilmu Pertanian dan Perikanan, 2 : 135-140.

Shubha, J., \& Srinivas, C. (2017). Diversity and extracellular enzymes of endophytic fungi associated with Cymbidium aloifolium L . African Journal of Biotechnology: 16: 2248-2258.

Shukla, N., Awasthi, R. P., Rawat, L., \& Kumar, J. (2012). Biochemical and physiological responses of rice (Oryza sativa L.) as influenced by Trichoderma harzianum under drought stress. Plant Physiology and Biochemistry 54 :78-88.

Sibero, M. T., Tarman, K., Radjasa, O. K., Sabdono, A., Trianto, A., \& Bactiarini, T. U. (2018). Production of fungal pigment and identification of its producer through DNA barcoding approach. JPHPI 21: 99-108.

Sitaresmi, T., Wening, R. H., Rakhmi, A. T., Yunani, N., \& Susanto, U. (2013). The Use of Local Variety Rice Germplasm in the Development of Improved Varieties. Iptek Tanaman Pangan $8: 22-30$.

Suciatmih, Yuliar, \& Supriyati, D. (2011). Exploration of Entophytic Fungi from Lowland Rice as a Biocontrol Agen of Blast Disease in Lowland Rice. Jurnal Teknologi Lingkungan 12 : 171-186.

Sucipto, I., Munif, A., Suryadi, Y., \& Tondok, E. T. (2015). Eksploration of Entophytic Fungi from Lowland Rice. Jurnal Fitopatologi Indonesia 11 : 211-218.

Sucipto, I., Munif, A., \& Tondok, E. T. (2016). Exploration of Endophytic Bacteria and Fungi as Biocontrol Agent of Blast Disease (Pyricularia oryzae) on Rice. Institut Pertanian Bogor.

Syamsia. (2016). Isolation and Identification of Endophytic Fungus on Local Aromatic Rice Plants of Enrekang. Agrotan $2: 61-67$.

Taurisia, P. P., Provorini, M. W., \& Nurantoro, I. (2000). The Effect Of Media On The Growth And Biomass Of Fungi Alternaria alternata ( Fries ) Keissler. Jurnal Biologi $19: 30-33$.

Teh Li Yee., \& Latiffah Zakariah. (2014). The first report of Penicillium georgiense in 
Malaysia. Mycobiology $42: 274-278$.

Uzma, F., Konappa, N. M., \& Chowdappa, S. (2016). Diversity and extracellular enzyme activities of fungal endophytes isolated from medicinal plants of Western Ghats, Karnataka. Egyptian Journal of Basic and Applied Sciences 3 : 335-342.

Y.W., H., Z.Y., C., S, S., K.D, H., H, C., \& M, S. (2009). Molecular phylogenetic identification of endophytic fungi isolated from three Artemisia species. Fugal Diversity : 69 - 88. Retrieved from www.Plants Journal.com

Yunianto, P., Rosmalawati, S., Rachmawati, I., Priyono Suwarsono, W., \& Sumaryono, W. (2012). Isolation and Identification of Endophytic Fungi from Srikaya Plants (Annona squamosa) Having Potential Secondary Metabolites as Anti-Breast Cancer Activity. Microbiology Indonesia $6: 23-29$.

Zhang, Y. and Li, D.C. 2012. Taxonomic studies of thermotolerant fungi. Department of Plant Pathology, Shandong Agricultural University. 